\title{
医療・健康記事をよくするためのメディア・ガイドラインの提案
}

\author{
小島正美
}

\section{Proposal for a Media Guideline to Improve the Medical and Health Journalism}

\author{
Masami Kojima \\ News Department for Living, The Mainichi Newspaper Co., Ltd.; Tokyo Head Office, \\ Corporate Headquarters, 1-1-1 Hitotsubashi, Chiyoda-ku, Tokyo 100-8051, Japan.
}

(Received February 3, 2012)

\begin{abstract}
A lot of healthcare professionals experienced annoyance with biased mass media news regarding medical and health issues. In this paper, I propose "news profiling method" and "media guideline" to improve the medical and health journalism.
\end{abstract}

Key words — news profiling method; media guideline; journalism; bias; risk communication

医療関係者の多くは，バイアスのあるゆがんだ医 療・健康ニュースに頭を悩ました経験があるはず だ。どう対処したらよいだろうか。私が提案したい のは，記者に「気づいてもらう」活動だ。その活動 を「ニュース・プロファイリング手法」という名前 にしてみた。

$$
\text { ニュース・プロファイリング手法 }
$$

プロファイリング手法とは何かを分かってもらう ため, 別の事例を挙げよう.

1997 年，小学生男児の頭が小学校の正門前に置 かれていた。世間の注目を集めた「酒鬼苗微聖斗」 事件だ。このとき，FBI（米国連邦捜査局）の心理 分析専門家は早くから「犯人は未成年だ」と分析し ていた.

犯罪捜査で活用される「心理学的プロファイリン グ」という手法を使つた成果だ。 心理学的プロファ イリングとは，犯行現場に残された限られた情報， 手口などから，犯人像を推定する方法だ。プロファ イルは，日本語では横顔とか簡単な人物紹介の意味 で使われるプロフィルのことだ.

この犯罪捜査の手法と同じようなことを，新聞や

毎日新聞社生活報道部（\%100-8051 東京都千代田区一 ツ橋 1-1-1)

e-mail: kojima-m@mainichi.co.jp

本総説は, 日本薬学会第 131 年会シンポジウム S33 で

発表したものを中心に記述したものである.
テレビに出てくるニュースでやってみようというの が私のアイデアだ。新聞記事の中身や表現，言葉か ら，記者のリスク思考の特徵を推論し，メディア情 報のゆがみ（バイアス）を探り出す。そして，分析 した結果を「プロファイリング情報」としてメディ ア側（記者）に提供し，今後，記事を書くときの参 考にしてもらおうというものだ.

これが「ニュース・プロファイリング手法」（私 の造語）だ。メディア情報をより正確で的確なもの にするための手法の 1 つだと考えてよいだろう.

具体的にどんなふうになるのか，私の考える事例 を紹介しよう。

プロトピック軟膏に関する記事への「気づき」

例えば，次のような報道（2010 年 3 月 21 日 共 同通信の配信）にどう対処すればよいかを考えてみ る.

「日本でも販売されているアステラス製薬の「プ ロトピック軟膏」(一般名はタクロリムス水和物) など 2 種類のアトピー性皮膚炎治療薬を使つた子ど もが， 2004 年 1 月 -09 年 1 月の 5 年間に計 46 人, 白血病や皮膚がんなどを発症し，このうち，4 人が 死亡したと米国医薬品食品局（FDA）に報告され ていることが分かった。

適応対象外の子どもに使つたり，長期間使い続け たりするなど，使用法が守られていないケースが多 いという。因果関係は明確ではないが，発がんと関 
連する恐れがあるとして，FDA は近く専門家会議 を開き，添付文書の改訂を検討する．FDAによる と，0-16 歳でプロトピックを使った 15 人，エリデ ル（スイスのノバルティス社の製品，日本では未発 売）を使った 27 人，両方を使った 4 人の計 46 人が 皮膚がんやリンパ腫，白血病を発症した。うち 50 \%は，添付文書で「使うべきでない」とされている 2 歳未満. $41 \%$ は安全性が確立していないと注意喚 起されている 1 年以上の長期使用。プロトピック使 用後にがんになった子どもの $26 \%$ は，有効成分濃 度 $0.03 \%$ の子ども用ではなく，濃度 $0.1 \%$ の大人用 を使っていた。 FDA は 05 年にも発がんと関連する 恐れがあるとして，使い方に注意するよう呼びかけ ている」

\section{「母数」も「対照群」もなしの欠陥記事}

たいていの人は，この記事を読んで，46人もの 子供たちが白血病や皮膚がんになったという数字の 大きさにまず驚くだろう。 5 年間で 46 人が皮膚が んや白血病を発症し，4 人が死亡したという数字を 知れば，怖いと思うのが普通だ。記事では「因果関 係は不明」と断っているものの，たいていの人は， この恐ろしい数字だけが頭に残り，「怖い」感情だ けが記憶に刻まれるはずだ。

しかし，ちょつと冷静に考えれば，この記事の欠 陥はすぐに分かる.

一番知りたいのは，何人の子供たちが使ったかで ある. 10 万人なのか， 100 万人なのか．数百万人な のか. 同じ 46 人の発症でも, 10 万人あたりと 100 万人あたりでは，危険度は全く異なる．

ところが，共同通信の記事には，こういう肝心な こと，つまり何人が使つたかの母数が書かれていな い。ささらに対照群も書かれていない。副作用情報の 意味も書いていない。こうして，肝心な点が分から ないまま，ネットではいろいろな反響が飛び交った。

こういう記事が出たときにまず知りたいのは, FDA がごういうことを公表したかだが，一般の人 がそれを知る手だてがない.

私が調べたところ，46 人の数字は，FDA の有害 事象報告システムに基づき，米国，英国，ドイツ， 日本など世界中の医療機関, 患者, 弁護士などから 自発的に報告された生の数字だ。これから FDAの 内部で検討するための未加工の数字をそのまま記者 が書いたようだ。当然ながら，「46人という数字

は，科学的な検証を経た数字ではない」（東京逓信 病院の江藤隆史皮膚科部長)。

記事が出たあとの 3 月 22 日に開かれた FDA 小 児諮問委員会では，540万人の子供たちが使ったこ とを報告している，46 人のうち，37 人が米国での 事例報告だった。米国で死亡した 4 歳の男児では約 3 年半も続けてプロトピックを使っていたことも分 かった.

こうした結果を基に，3 月 22 日に同委員会は 「いままで以上の警告を支持しない」との見解を出 している。 540 万人のうちの 46 人の発症率は，警 告を出すほどのリスクではないと判断したのだ.

共同通信は 22 日の小児諮問委員会の見解を報道 してもよさそうなのに，肝心なことは報道していな い. 報道したことをフォローする責任感のなさが分 かる.

日本ではプロトピック軟膏を使っている患者は, 小児（0-16 歳）で約 20 万人，大人で約 50 万人も いる (アステラス製薬の推定). 500 万人が使って, 46 人の発症率は, 塗り薬を使っていない通常の皮 膚がんやリンパ腫の発生率と比べて，高いとは言え ない.

\section{プロファイリングの手紙を出す}

こうした考察結果から，ニュース・プロファイリ ングを実践する場合，共同通信に次のような手紙を 送る行動に出る.

「扯啓 共同通信. ○○日に報道されたプロトピ ック軟膏に関する記事は，母数にふれず，しかも FDA の最終的な見解を報道しないという非常に偏 つた内容になっております。これでは，読者にプロ トピック軟膏の恐怖情報を提供するだけに終わって しまいます。ぜひ，科学的な根拠に従った続報を期 待しております。次のような先生方に取材して頂け れば，免疫抑制剂に関する的確な情報が得られます」 こういう手紙を出す場合，記者が取材し易いよう に研究者の取材先リストを載せておくことが必須条

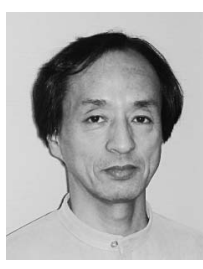

小島正美
1951 年 12 月, 愛知県生まれ. 愛知県 立大学卒. 1974 年, 毎日新聞社に入 社, 長野, 松本支局を経て, 東京本社 生活家庭部に配属. 1997 年から生活報 道部編集委員. 2000 年から東京理科大 学非常勤講師も兼務。著書は「正しい リスクの伝え方」（エネルギーフォーラ ム) など多数. 
件なのを覚えておきたい.

この気づきの手紙は「訂正」の要求ではない.

仮に訂正を求めても，向こうは「間違ってはいな

い」と反論してくるだろう.

「抗議」という形式をとつても同じ反論が来るだ ろう。

このプロファイリング手法は，記者に「気づいて」 もらい，次回からきちっとした記事を書いてもらう のが目的だ。

訂正や抗議が無理でも，あきらめてはいけないの である.

プロファイリング手法の活動は，記事の書き方の モデルを提示することまで考えるとなおよい，記事 のパターンを示すことで，より正確な事実が読者に 届くことを考えようという狙いだ.

その際に記者がよく間違う事例も添えておくとべ ストだ.

そのよい例が薬の効果だ.

\section{絶対リスクと相対リスク}

例えば，A という薬で「心臓病によって死ぬ人 が $50 \%$ も減りました」と聞くと，たいていの人は ものすごく効く薬だと思うだろう。「50\%も減る」 という数字のトリックにだまされてしまうのだ.

「50\%も減る」という数字を，パーセントで考え てみる，例えば，死ぬ人が「8\%から $4 \%$ に下がつ

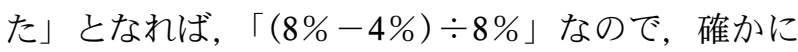
$50 \%$ の減少率になる。これが相対的なリスクの減少 率だ。しかし，絶対的なリスクの減少は，8\%-4\% $=4 \%$ に過ぎない.つまり，4 ポイント下がっただ けだ.

この薬が 10 万人に投与されたとしよう。そうす ると，薬のなかったときは 8 人（仮に 8 人とする） 死んでいたが，薬の登場で死亡者が 4 人に減つたと いう例になる. 8 人が 4 人に減つたのだから，薬の 効果は確かに $50 \%$ ある。しかし，絶対的な数で見 ると，10万人のうち，以前は 8 人死亡していた が，薬のおかげで 4 人が死ななくなつたという意味 なので, 助かるのは 10 万人のうち, わずか 4 人だ.

言い方で印象はがらりと変わる.

「A 薬は 10 万人のうち，4 人の死亡を減らしま す」という言い方と，「A 薬は 10 万人への投与で, 死亡率を $50 \%$ も減らします」という言い方では, ごちらがより効果的に聞こえるだろうか．後者の相
対効果の方が効果的に聞こえるはずだ.

2 倍という言い方も， 10 万人のうち 1 人が 2 人に 増えても 2 倍だし， 10 万人のうち，1000人から 2000 人に増えても 2 倍だ。もちろん気をつけねば ならぬのは絶対的なリスクの高い後者の方だ。相対 リスクよりも，絶対リスクを見るくせを身につけて おきたい.

こういう基礎的な情報も一緒に載せて発信すると よい.

\section{伝える情報は「3つ」にしばる}

話はプロファイリングにもどる。

プロファイリング情報を記者に伝えるときに知つ ておくべきテクニックがある.

科学的な情報を伝えたからといって，その中身が 記者の心に確実に伝わるわけではない．科学的な情 報の「伝え方」を知っていないと，せっかくのプロ ファイリング情報も台なしになる.

そのポイントをいくつか挙げてみる.

1 つは，簡潔にまとめて送ることだ。A4 サイズ の用紙 1-2 枚に重要なポイントを書く。これが肝要 である。だらだらと書いても，読んでくれない。

要約は 3 つのポイントにまとめる.

ぞんなケースでも，3つの要約にまとめるのがコ ツだ．なぜ 3 つなのか．人が理解するのにちょうど よい長さだからだ．2つでは少なすぎ，4つだと多 い. 心理的にぴったりくるのが「3」という数字だ.

記事を書くときに，どんなことに気をつければ， よい医療記事ができあがるかについてこのプロファ イリング手法は，記事やニュースが出たあとのアク ションだ.

一方，記者が記事を書くときに参考にしてもらう のが，メディア・ガイドラインだ.

つまり，記事を書くときに知っておいてほしい項 目を事前にテキストの形で記者側に送っておく，記 者はこの項目をチェックしながら，記事を書くとい うわけだ.

事前のメディア・ガイドラインと事後のプロファ イリング手法がセットになれば，一番効果的だろう。

例えば，以下の 10 項目が私なりにつくつた「メ ディア・ガイドライン」の試案だ.

1.「あなたが書こうとしている記事は，科学的 な根拠に則ったデータがあるかどうか」

記事に出てくる話が体験談や一学者の意見な 
ら，エビデンスのレベルは非常に低い。人を対 象にした比較対照臨床試験かどうか．科学論文 として名の知れた専門雑誌に出たかどうか，そ して，論文に書かれた内容は複数の論文によつ て支持されているかどうか.

2.「新しい事実かどうか。なぜ新奇性に富むか を書いているか」

記事やニュースはたいていの場合，なにかし ら新しい事実に違いないが，従来の通説とどこ がどう異なるかがはっきりしているかどうか.

つまり，なぜ，記者がニュースにしたかの根 拠，理由が記事の中に説明されているか.

3.「国や学会など，公表した主体が伝えようと した意図が記事に入っているかどうか」

そもそも記事やニュースは，記者が主観的な 観点で伝えるものだが，発表記事では，発表し た側の意図が正確に伝わつたかどうかが重要に なる。いくらおもしろい記事でも，記者の勝手 な解釈で読者を惑わすものであってはならな い. 発表側が何を伝えようとしたかが分からな いことには，記事の善し悪しを判断することは 難しいことを知っておく.

4.「リスクが分かり易く伝わっているか」

いくら科学的に正確でも，読み手に伝わらな ければ意味がない。リスクの大きさが分かり易 く提供されているかどうか. リスクのレベル が，例えば，「自衛策が必要なレベル」といっ たふうに，数字や言葉で分かり易く書かれてい れば合格である.

5.「情報源に偏りがないか」

健康・医療記事では, 科学的な根拠の低い段 階で，私企業が「この健康食品はがんに効果」 といった感じでニュースを流す場合があり，そ れを記事にすることがよくある，だれが，どう いう目的で発表したかが分かる記事だと評価は 高い。健康食品を売りつける目的で記事が書か れていれば，その記事に出てくる健康食品の効 果は低いと言えるが，記事自体の信頼性は高 い.こういうケースでは視点によって評価は分 かれるだろうが，記事の中身から，明らかに私 企業寄りの情報源に頼っていると分かれば，私 自身は，記事自体は信頼できると考える．情報 源をぼかして，あたかも信憑性があるかのよう
に見せかけた記事こそ要注意である.

6.「研究がどういう資金で実施されたか具体的 に書いてあるかどうか」

研究資金が国から出たものか, 私企業の助成 で行われたかが明確に書かれているかどうか. どこが資金を提供したかによって，研究結果が 微妙に変わるだけに，この資金源の情報は重要 である．ただし，国の税金を使ったからといっ て，その研究が正しいわけではない，国の研究 でも，結果に偏りがある場合はよくあるからだ.

7.「費用対効果に触れているかどうか」

ぞんなにすぐれた治療法が生まれても，費用 （医療コスト）があまりにも高ければ，一般の 人が医療を受けることができず，意味がない. また，費用が高くなくても，効果が低いのであ れば，これまた意味がない。健康保険の適用と なっているかどうかも重要である，結局，どれ だけの費用をかけて，民゙れくらいの効果がある かを分かり易く伝えた記事がよい記事となる.

8.「リスクとベネフィットに触れているかどう か」

医薬品の副作用がしばしば強調された記事を よく見る．しかし，副作用があっても，それだ けでは薬の使用を禁止する根拠にはならない。 リスクを上回る便益（人の命や生活の質を助け る有用性）があれば，すぐれた医薬品とも言え る。リスクとベネフィットを冷静に比較した記 事なら信頼性は高い.

9.「消費者が何をすればよいかが，読み取れる かどうか」

国が発表した内容に，記者たちがさらに分か り易い解説をつけて，この件で消費者はこうす ベきだといつた行動へのアナウンス指針があれ ばよい記事だろう。

10.「センセーショナルな見出しになっていない か。本文でも過剩な期待や不安を与えていない かどうか」

記事の中身（本文）は正しくても，見出しが 不安や恐怖をあおる，というケースがよくあ る. センセーショナルな見出しはかなりの減点 としたい，例えば，ある治療法やサプリメント に治療や健康効果があると書いてあっても，現 実には支持する科学者が少ない場合がある。過 
剰な期待を抱かせる記事も減点となる.

また，最後に補足したい.

ニュースを読み解く能力を高めるために，一般市 民向けにニュースの特色を知ってもらう基本項目を 記述したガイドブック（リスク理解ハンドブック） のようなものをつくっておくのもよいだろう。ぜ ひ，実践してほしい。

例えば，メディア情報を読み解く基本として，以 下が考えられる。

1. メディア情報はすべて構成されたもの，バイ アスがある。情報は現実をそのまま映し出した ものではない.

2. メディアは現実をある視点から構成する.

3. 同じ情報に，読み手はみな違った見方をす
る．読み手は自分にとって都合のよい，また心 地よい記事を受け入れる。

4. メディア情報は商品だ。利益を得ないと続か ない.

5. メディアは価值観や道徳も伝えている．よい 生活とはどういうものか，素敵な女性はどうい う女性か，カッコよい男はどういう男か，な ぞ.ジェンダー的な視点が紛れ込む.

6. メディアは政治的な意味も伝える. 弱者の立 場にたつて報道，政府への批判をつづけ，現体 制を変えたい，など.

7. 読夕解く力を持つことでメディアを変えるこ とができる．楽しむこともできる． 